\title{
Analysis of Factors Affecting Consumer's Purchase Intention Impact on Customer Behavior Outcomes
}

\author{
$1^{\text {st R.A. Marlien }}$ \\ Faculty of Economics and Business \\ Universitas Stikubank \\ Semarang, Indonesia \\ marlien@edu.unisbank.ac.id \\ $3^{\text {rd }}$ R. Basiya \\ Faculty of Economics and Business \\ Universitas Stikubank \\ Semarang, Indonesia \\ rbasiya@edu.unisbank.ac.id
}

\author{
$2^{\text {nd }}$ CindyNoviani Putri \\ Faculty of Economics and Business \\ Universitas Stikubank \\ Semarang, Indonesia \\ cindynoviani28@gmail.com \\ $4^{\text {rd }}$ Bambang Suteja \\ Faculty of Economics and Business \\ Universitas Stikubank \\ Semarang, Indonesia \\ bangjo@edu.unisbank.ac.id
}

\begin{abstract}
Private Label is a merchandise that uses the brand name of the distributor or retailer or the brand name created for the distributor or retailer. The purpose of retailers to make private label products to meet consumer needs and the existence of private label products has become a trend among retailers. Private label products have their own designs by retailers and are developed using the name of the retailer concerned, private label products are only sold by the company.The purpose of this study was to analyze the influence of Brand Image, Quality Perception, Price Perception, and Value Perceptions on the Purchase Intention have an impact on CBO of Indomaret private label products in Semarang City. The population of this study is all
\end{abstract}

\section{INTRODUCTION}

Business competition is currently very competitive where product brands not only compete with other manufacturers' brands, but also compete with unbranded (generic) products and private label products.Private label products, have recently developed very fast, so that they can shift the power of producers to retailers.Private label is a product that is sold in a shop(retailer) with a brand that is specially made by the store(retailer). Private label is also known as a store brand. This private label strategy is commonly carried out by modern retailer networks.

Products that use a lot of private label are usually Fast Moving Consumer Goods (FMCG) products and generic products, where the price is inexpensive, used immediately, and requires little consideration in purchasing decisions.Consumers of this private label are consumers who have little brand loyalty because they are very price sensitive. Therefore, for national brand FMCG producers, the presence of private label is a threat that can erode their market[1].

The growth of the modern retail business in Indonesia creates competition in the world of modern retailbecoming increasingly stringent. This condition causes retailers to

\begin{abstract}
Indomaret consumers in Semarang City whose numbers cannotbe known. Samples were

taken as many as 100 respondents. The data used are primary data. Data obtained directly from Indomaret consumers in the city of Semarang through the questionnaire method.The results of this study indicate that, brand image, quality perception, price perception, and value perception have a significant positive effect on the purchase intention. However, purchase intention has no effect on CBO
\end{abstract}

Keywords: Brand Image, Quality Perception, Price Perception, Perception Value, Purchase Intention, Private Label Products, Customer Behaviour Outcomes (CBO)

find the right strategyin order to compete with other modern retailers and retain customers, one strategy adopted by every modern retailer is to compete on product prices.

The cheaper the product being sold, the more it will attract customers to shop.Of course, the private label products owned by modern retailers will not be separatedconsumer assessment based on the perceptions of each consumer. Perceptionconsumers are very vital in the modern retail business, because of their behaviorconsumers for a product and consumer satisfaction is also influenced by perceptionconsumers.The better the consumer's perception of a product, will bethe higher the level of consumer loyalty to the product and not closeis likely to also have a positive effect on revenue and retail developmentmodernity. Vice versa, the worse the consumer's perception of somethingproducts, consumer loyalty to modern products and retail will be low.

According to [2] the Indonesian people still think thatNational brands have a greater good value for money 
than productsprivate label.The price of private label products is always more

cheap compared to national brand products. Therefore a cheaper price,the majority of consumers also think that the quality is worse.

\section{LITERATURE REVIEW AND HYPOTHESIS}

a. Private Label-Private label is a private branding strategy that refers to the descriptionon the types of products provided by suppliers to the retail industry(retail) that bear the respective retail outlet brand names. Privatelabel can also be referred to as a private brand, store brand, or own label.Private label is often seen as a product with second-class quality by consumers[3]. Some of the causes include:

1. The packaging is simple and tends to be unattractive. 2. Prices are slightly cheaper compared to national brand products already famous first. 3. Little product diversity. 4. Lack of promotion from retailers themselves to their products. 5. Consumers are accustomed to using products with national brands, so they have knowing the quality and then reluctant to try products with private brands. 6 . Private Label does not have a good image in a certain product category. The personal brand is considered not to have an added value for consumers whobeen fanatical about products with national brands.

b. Brand Image-Brand image is a consumer's assessment of a set of brand associations that are already stored in the minds of consumers. This creation can be created based on personal experience or hearing about its reputation from other people or the media[4];[5]are: Recognition, Reputation, Affinity Loyality.

c. Perception of Quality-Perceived quality as a consumer's perception of the quality or superiority of a product or service in relation to the goals it wants, compared to other alternatives. In other words, perceived quality is a consumer's subjective opinion of the superiority of an overall brand. Meanwhile, according to[6], perceived quality is the consumer's perception of the quality or superiority of a product or service in terms of its function relative to other products.

d. Perception of Price-Price perception is a consumer judgment and an associated emotional form regarding whether the price offered by the seller and the price compared to other parties makes sense, is acceptable or can be justified. According to[7]price perception is how price information is fully understood by consumers and provides deep meaning for them.

The indicators in this study use research according in[8], namely: Product price affordability, price compatibility with product quality, product price competitiveness, compatibility with product benefits.

e. Perception of Values-Value is the overall customer assessment of the usefulness of a product based on perceptions of what is received and what is given. The perception of measuring value is based on monetary and non-monetary costs combined with perceptions of quality.
The indicators in this study used the research of [9], namely: Emotional Value, Social Value, Quality Performance Value, Price / Value of Money.

f. Puschase Intention-Purchase intention according to [10]is a decision taken by consumers to buy a product/brand. In other words, purchase intention is an intention and desire that consumers have to buy certain products or brands.[11]state that consumer purchase intention is the desire and tendency of consumers to buy advertised products because there is a possibility that consumers will buy these products in the future.

The indicators in this study use research according to[12]Transactional, Referential, Preferential, Explorative.

g. Customer Bahavior Outcomes-Customer satisfaction is a critical factor to generate customer loyalty[13];[14]. The key to the buying behavior of the future. Repurchase intention indicates an individual's willingness to make another purchase from the same company, based on his/her previous experiences [15]; [16]Customers who are satisfied with the service provided by a service providers will behave positively would increase the usage level and future usage intentions[14]. Customer satisfaction and repurchase intentions can be increased by offering superior service quality[17][18]. When customers are satisfied with the product or service they buy, they tend to purchase again from the same supplier. Several studies have found evidence for a positive relationship between customer satisfaction and repurchase intentions[19];[20].

\section{The Relationship Between Variables And Hypothesis}

A well-communicated brand image can helpbuild brand position, protect the brand from competition, improve performancebrands in the market, and therefore play an integral role in building long-term brand equity[4]; [21];[22]

prove that brand image has a significant effect on consumer purchase intentions. This shows that if the brand image variable increases, there is a tendency for consumer purchase intentions to also increase.

$\mathrm{H} 1$ =Brand imagehas a positive effect on purchase intention

[4]; [23]states that the perception of good quality in the eyes of consumers will increase the intensity of purchases because it provides a strong reason in the minds of consumers to choose the product or brand. Consumers view of quality must be maintained properly because it can affect consumers' intention to buy a product [10].

$\mathrm{H} 2$ =perceived quality has a positive effect on purchase intention

Perceived price shows consumer sensitivity to price variations. A person with a greater perceived price is described as less willing to buy the product.

Consumers are attracted to a fair price. The prices arefair means the perceived value is appropriate at the time the transaction is carried out.Consumers assume that a product with a high price means a lothas good quality, whereas if the price is cheap it hasthe quality is not good. 
Research conducted by[24] stated that consumers will buy a branded product ifthe price is considered by them. $\mathrm{H} 3=$ Perception pricehas effect on purchase intention

An important factor in the consumer purchasing decision process and consumers will buy products with high value. In other words, the higher the consumer's perceived value, the higher the consumer's purchase intention, which means that the perceived value has a positive influence on purchase intention.

[25]perceived value variable has a positive and significant effect on purchase intention. This shows that if the value perception variable increases, there is a tendency for consumer purchase intentions to also increase.

$\mathrm{H} 4$ = perceived values has a positive effect on purchase intention

Intention is a combination of trust from consumer attitudes towards products and services. Purchase intention is a determinant of purchase to carry out an action such as buying a product or service. Satisfied customers will behave positively by making repeat purchases[14]. The better the attitude and subjective norms towards a buying behavior, and the greater the behavioral control he feels, the stronger the consumer's intention to make purchases. The stronger the consumer's intention to make a purchase or achieve the purchase goal, the greater the success of predicting the behavior or behavioral goals will occur.

$\mathrm{H} 5$ = Purchase intentionhas a positive effect on $\mathrm{CBO}$

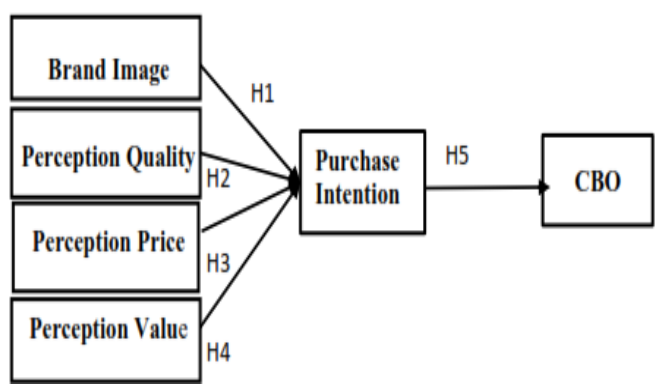

Fig 1: Research Model

\section{RESEARCH METHODS}

The number of samples in this study was set at 100 respondents. The sampling technique used was purposive sampling with the criteria being respondents who were at least 17 years old, purchased private label products, and were willing to provide information.

\section{RESULTS AND DISCUSSION}

The results of the validity test show the value of KMO MSA> 0.50. The results of testing the validity of KMO Brand image $=0.709$, Perception quality $=0.597$, Perception price $=0.645$, Perception value $=0.553$, Purchasing intention $=0.735$ and $\mathrm{CBO}=0.763$. All variable indicators are above a loading factor of 0.4 , meaning that all indicators are valid.Reliability test states that the variables Brand image $=0.705$, Perception quality $=0.872$, Perception price $=0.701$, Perception value $=0.83$,
Purchasing intention $=0.735$ and $\mathrm{CBO}=0.727$ are already above the Cronbach Alpha value> 0.7 means these variables declared reliable and can be analyzed further.

Adjusted R Square value of 0.936 means that the independent variable is able to explain $93.6 \%$ of consumer purchase intentions, while the remaining $6.4 \%$ is explained by other variables not included in this study.Obtained the calculated F value of 365.606 with a significance value of 0.0 smaller $5 \%$, it means that the research model used is fit or feasible.

Table 1: Regression Test

\begin{tabular}{|c|c|c|c|c|}
\hline $\begin{array}{l}\text { Purchase } \\
\left.\text { Intention( } \mathbf{Y}_{1}\right)\end{array}$ & (Adj R R & $\mathbf{F}$ & Beta & Sig \\
\hline $\begin{array}{l}\text { Brand lmage } \\
\left(X_{1}\right)\end{array}$ & \multirow{4}{*}{93,6} & \multirow{4}{*}{62,99} & 0,304 & 0,0 \\
\hline $\begin{array}{l}\text { Perception } \\
\text { guality }\left(\mathrm{X}_{2}\right) \\
\end{array}$ & & & 0.244 & 0,0 \\
\hline $\begin{array}{l}\text { Perception } \\
\text { price }\left(\mathrm{X}_{\mathrm{s}}\right)\end{array}$ & & & 0,145 & 0,002 \\
\hline $\begin{array}{l}\text { Perception } \\
\text { value }\left(\mathrm{X}_{4}\right)\end{array}$ & & & 0,373 & 0,0 \\
\hline $\mathrm{CBO}\left(\mathrm{Y}_{2}\right)$ & (Adj R R) & $\mathbf{F}$ & Beta & Sig \\
\hline $\begin{array}{l}\text { Purchase } \\
\text { Intention( }\left(Y_{1}\right)\end{array}$ & 0,011 & 2,093 & 0,145 & 0,151 \\
\hline
\end{tabular}

Model 1: $\mathrm{Y}_{1}=0,304 \mathrm{X}_{1}+0,244 \mathrm{X}_{2}+0,145 \mathrm{X}_{3}+0,373 \mathrm{X}_{4}$ Model 2: $\mathrm{Y}_{2}=0,145 \mathrm{Y}_{1}$

The model above shows that the four variables have a positive effect, meaning that the increased brand image $(\mathrm{X} 1)$, perception quality, perception price, perception value will increase consumers' purchasing intention and all of teh variables have effect significant. Of the four variables, the most dominant variable is perception value.Model 2 shows purchase intention has a positive effect on $\mathrm{CBO}$ but not signifaicant.

The four hypothesis show that all are accepted with a significance level of less than $5 \%$. The fifth hypothesis is rejected because the significance level is above $5 \%$.

\section{Discussion}

Brand Image is how customers think of a brand. It can be defined as the perception of the brand in the minds of the customers.In this study, consumers' views on private label products are still diverse. In general, consumers like the existence of these products to meet their daily needs, Fast Moving Consumer Goods (FMCG). However, there are still consumers who do not like the presence of these products around $30 \%$, this is because consumers still believe in branded products. As research conducted by Yonathan and Sukirno (2015), brand image has a significant effect on consumer purchase intentions.

Perceived quality is your customers' view of the quality of a product or service both in terms of what they expect and also in comparison with how they perceive the quality of competing offerings. That means perceived quality is defined as a measure of belief. Consumers' perceptions of the quality of private label products are very good with affordable prices and almost the same quality as branded products, although there are still those who disagree. This is a concern of shops that issue their own 
products to convince consumers. Research that reveals indirect effects between perceived product quality and purchase intention through customer mediation variables satisfaction[17];[26].

Consumers do not always know or remember the true price of a product or service. Instead, they make prices meaningful to them and remember prices as simply "cheap" or "expensive" [27]. The objective price is the amount of money needed to buy the product. Psychological price, respectivelyconsumers' internal perceptions of prices.In this study, price perceptions in the minds of consumers are affordable according to the sacrifices incurred. The price of private label products is very affordable for price sensitive consumers, considering that private label products are daily necessities.

Perceived value has been argued to be the most important indicator to forecast purchase intentions and has been viewed as one of the most important measures for gaining a competitive advantage [28] ; [24]; [18]. Perceived price fairness has a effect on purchase intention. The results of this study are in accordance with research conducted [25] which states that perceived value has a positive and significant effect on purchase intention.

The purchase intention of consumers of private label products has the potential to become a competitor for branded products that are well known to consumers. Although in terms of lower prices, the perception of product quality is almost the same, on the other hand, private label products are still limited to products of daily necessities. In this study, consumer purchase intention has no effect on CBO.

\section{CONCLUSION}

Private label products are an alternative choice for daily necessities. Its existence is well known by the public for products with lower prices and almost the same quality as branded products, although they are still limited to products for daily necessities. In this study, the model proposed by brand image, perceived quality, perceived price and perceived value affects consumer purchase intention. However, this model cannot prove that high purchase intention has not been able to influence customer behavior to repurchase or that loyalty is still low.

\section{REFERENCES}

[1] M. Kurnianto, "Strategi Merek," Impian Dan Masa Depan, Apr. 29, 2019. https://muhdikurnianto.com/2019/.

[2] I. F. Tannur, "Keunggulan Private Label Dibandingkan Merek Nasional Pada Ritel Hypermarket," Jurnal Ilmiah Mahasiswa Manajemen, vol. 2, no. 4, 2013.

[3] K. Kapferer, J J., "The New Strategic Brand Management: Creating and Sustaining Brand Equity Long Term," London and Philadelphia, 2008.

[4] D. A. Aaker and B. Alexander L., "Brand Equity \&Advertising: Advertising's Role In Building Strong Brands," New Jersey: Lawrence Erlbaum Associates, Inc., 1993.

[5] F. Rangkuti, Strategi Promosi Yang Kreatif, 1st ed. Gramedia Pustaka Utama, Jakarta, 2009.

[6] S. Claudia, "Hubungan Antara Persepsi Terhadap Kualitas Produk Dengan Kepuasan Konsumen Pada Mahasiswa Fakultas Psikologi Universitas Muhammadiyah Surakarta Pengguna Smartphone Iphone," Fakultas Psiklogi. Universitas Muhammadiyah Surakarta, 2017.
[7] J. P. Peter and J. C. Olson, Consumer Behavior Perilaku Konsumen, 4th ed. Penerbit Erlangga. Jakarta, 2000.

[8] F. Malik, "The Impact of Price Perception, Service Quality, and Brand Image on Customer Loyalty: Study of Hospitality Industry in Pakistan," Interdisciplinary Journal of Contemporary Research in Business, vol. 4, no. 5, 2012.

[9] C. Chua and J. C. Sweeney, "Customer Participation in Service Production," 2003.

[10] E. Purwanto and A. Wibisono, "Pengaruh Country Of Origin, Word Of Mouth, Kualitas yang Dipersepsikan Terhadap Niat Beli," Jurnal Riset Manajemen dan Bisnis (JRMB) Fakultas Ekonomi UNIAT, vol. 4, no. 3, pp. 365-374, 2019.

[11] Q. U. A. Zafar and M. Rafique, "Impact of Celebrity Advertisement on Customers Brand Perception and Purchase Intention," Asian Journal of Business and Management Sciences, vol. 1, no. 11, pp. 53-67, 2013.

[12] A. Ferdinand, 2002. Pengembangan Minat Beli Merek Ekstensi Badan Penerbit Universitas Diponegoro.Badan Penerbit Universitas Diponegoro. Semarang, 2002.

[13] A. links open overlay panelThi S. H. Pham and M. F. Ahammad, "Antecedents and Consequences of Online Customer Satisfaction: A Holistic Process Perspective," Technological Forecasting and Social Change, vol. 124, pp. 332-342, Apr. 2017, doi: https://doi.org/10.1016/j.techfore.2017.04.003.

[14] Marlien, R.A, Dampak Nilai Ciptaan-Bersama Berdasarkan Kolaborasi Bersinergi Terhadap Capaian Keperilakuan Pelanggan, 1st ed. Fakultas Ekonomika dan Bisnis-UKSW, 2018.

[15] R. Filieri and Z. Lin, "The role of Aesthetic, Cultural, Utilitarian And Branding Factors In Young Chinese Consumers' Repurchase Intention Of Smartphone Brands," Computers in Human Behavior, vol. 67, pp. 139-150, 2017.

[16] P. K. Hellier, "Customer Repurchase Intention A General Structural Equation Model," European Journal of Marketing, vol. 37 , no. $11 / 12$, pp. $1762-1800,2003$, doi: 10.1108/03090560310495456.

[17] J. J. Cronin, Jr and S. A. Taylor, "SERVPREF vesus SERQUAL: Reconciling Performance-Based And Perception-MinusExpectations Measurement Of Service Quality," Journal of Marketing, vol. 58, no. 125-131, Jan. 1994.

[18] J. J. Cronin. Jr, M. K. Brady, and G. T. M. Hult, "Assessing The Effects Of Quality, Value, And Customer Satisfaction On Consumer Behavioral Intentions In Service Environments," Journal of Retailing, vol. 76, no. 2, pp. 193-218, 2000, doi: 10.1016/S0022-4359(00)00028-2.

[19] M. Blut, "E-Service Quality: Development of a Hierarchical Model," Journal of Retailing, Elsevier, vol. 92, no. 4, pp. 500517, 2016.

[20] O. Kitapci, C. Bozpolat, and I. T. Dortyol, "The Impact of Service Quality Dimensions on Patient Satisfaction, Repurchase Intentions and Word-of-Mouth Communication in the Public Healthcare Industry," Procedia - Social and Behavioral Sciences, vol. 148, pp. 161-169, 2014, doi: 10.1016/j.sbspro.2014.07.030.

[21] Keller and K. K. Lane, "1993. 'Conceptualizing, Measuring, and Mananging Customer-Based Brand Equity'.," Amerika : Journal of Marketing, vol. 57, no. 1, 1993.

[22] X. Bian and L. Moutinho, "The Role Of Brand Image, Product Involvement, And Knowledge In Explaining Consumer Purchase Behaviour Of Counterfeits Direct and Indirect Effects," European Journal of Marketing, vol. 45, no. 1/2, pp. 191-216, 2011, doi: 10.1108/03090561111095658.

[23] J. L. Aaker, "Dimensions of Brand Personality," Journal of Marketing Research, vol. 34, no. 3, pp. 347-356, 1997, doi: 10.1177/002224379703400304.

[24] W. B. Dodds, K. Monroe, and D. Grewal, "Effects of Price, Brand, and Store Information on Buyers' Product Evaluations," Journal of Marketing Research, vol. 28, no. 3, 1991.

[25] M. S. Yonathan and Ign. Sukirno, "Pengaruh Persepsi Nilai, Persepsi Kualitas, Persepsi Harga Dan Citra Merek Terhadap Niat Beli Produk Pakaian Nevada: Studi Pada Mahasiswa Di Fakultas Ekonomi Universitas Atma Jaya Yogyakarta," Fakultas Ekonomi Universitas Atma Jaya Yogyakarta, p. 2015. 
[26] J. C. Sweeney and G. Soutar, "Consumer Perceived Value: The Development of Multiple Item Scale," Journal of Retailing, vol. 77, 2001.

[27] V. A. Zeithaml and K. L. Graham, "The Accuracy of Reported Reference Prices For Professional Services," Advances in Consumer Research, vol. 10, pp. 607-611, 1983.
[28] Parasuraman, A, V. A. Zeithaml, and L. L. Berry, "Servqual: A Multiple-Item Scale For Measuring Consumer Perception Service Quality,” Journal of Retailing, vol. 64, no. 1, 1988. 